\title{
EXTERNAL RESOURCES IN MILITARY LOGISTICS - THEORY AND IMPLEMENTATION
}

\author{
Stanislav MORONG \\ The Armed Forces Academy of General Milan Rastislav Štefánik, \\ Liptovský Mikulás, the Slovak Republic \\ stanislav.morong@aos.sk
}

\begin{abstract}
The article focuses on the specific status of the Armed Forces in the implementation of outsourcing, as one of the cost-benefit optimization methods in military practice. The author points out the need for a comprehensive and strategic monitoring and estimation of the costs, as an elementary assumption of the effective use of public financial resources. Implications of projects implemented without adequate economic analysis are shown on the example of the services outsourcing in military logistics in the Armed Forces of the Slovak Republic.
\end{abstract}

KEYWORDS: costs, external supplier, services, military logistics, resources

\section{Introduction}

The Armed Forces are a company with a unique transformation process, which is defending the state. The security of citizens against the threats of the external environment is a public service provided by all the forces and means appropriate to an emerging threat.

Given forces and means are quantitatively and qualitatively limited by disposable financial resources, which the state or a military alliance decide to spend on defence. Financial resources are being spent in this context not only on armament, military vehicles and material basis necessary for the provision of logistic support. A significant portion of the budget of the Ministry of defence is intended to finance intangible forms of the logistic support, and that is the provision of logistics services.
Thus the provision of logistics services and making stocks for a time of crisis situations are essential differences between the enterprise and the armed forces in the context of the structure and a formation of the cost.

One of the options for strengthening the competitive position of the enterprise on the market is the effort on implementation of cost optimization methods into the transformation process, for example by using the method "Just in Time", the enterprise minimizes the cost of maintaining inventory. It creates the preconditions for the use of financial resources to be invested in expansion of production, development of new products, or improvement of quality.

Other eventuality of the cost optimization is its comparison when making decision on provision of supporting 
activities. There are two alternatives as a variant solution for the enterprise. The use of internal resources of the enterprise or the selection of an external supplier, depending on the amount of the costs of each of compared variants.

The use of cost optimization methods, as well as development of inventories along the lines of a corporate practice, have a special status, limits and restrictions within the armed forces.

The failure of an exceptional position of the armed forces in the implementation of selected instruments of the economic practice into the processes of military logistics has critical consequences for safeguarding security of units and facilities of the Ministry of Defence. In the case of a state of war or emergency situations of war, it is appropriate to talk about a fatal impact on the operational capability of the armed forces.

\section{The Cost Analysis - Importance and Experience}

Management of the enterprise, in addition to other objectives when deciding on the cost in the form of possible externalization of selected services, focuses on two basic goals:

- reducing the costs;

- concentration on the core business.

In meeting these objectives, and due to the fact that it decides on its own available resources, it focuses on a comprehensive cost estimate for service throughout the period of its provision. It compares the cost of the service provided by its own resources with any service provided by an external supplier.

In the same decision process, the defence department is not confronted with the necessity of management of private resources. And the fact, that it decides on public funds which have been allocated within the budget, does not generate sufficient pressure to take responsibility for the resources entrusted and the decisions taken. Despite the fact that, in the framework of the Alliance, and also at the national level, the matter of cost optimization has been relatively sufficiently processed.

Tracking the cost of the life cycle of the products of the defence industry or a significant non-military material is a contain of a number of Allied documents. A significant fact is that the relevant of them (AAP - 20 NATO, 2015) categorize the life cycle of the system into seven stages, where it is necessary to keep track of the cost.

In the structure of defence of the Slovak Republic, the subject, which is responsible for processing cost estimate on the life cycle of a system for the acquisition, is absent. It is understandable, that the department, which would comprehensively study the cost of the life cycle of the system, is not even available. Currently, within the department, the costs are monitored partially by individual units and facilities according to their needs and within a limited range.

It is one of the reasons why, in the past, the Defence Department senior management focused on the immediate or short-term effects achieved by the acquisition of resources from the external environment. Decisions of this type were based more on intuition, or, what is even worse, on political decisions rather than on information based on serious economic analysis.

By flagrant violation of an infringement of general principles in use, which are applied by the enterprise when deciding on outsourcing (externalisation) of selected services, not only inefficient spending of financial resources but also the loss of logistical capabilities have occurred in the Defence Department.

\section{Consequences of Non-Respecting} Structure Estimates and Cost Levels

A typical example of the decision, which did not have any support in the implementation of strategic objectives in military logistics in a comprehensive estimate of the possible structure and life cycle costs, is the project of outsourcing of selected logistics services (ŠbLog-V-277/2004, 2004). 
On the basis of the project which continued in the project (USANM-915/2007-OZS, 2007) in the area of outsourcing, following services have been selected in the Armed Forces of the Slovak Republic:

- meals;

- on site security;

- heating economy;

- cleaning;

- laundering, cleaning and repairing of clothing and linens;

- operation services of wastewater treatment plants, water resources and hydrophore stations.

When deciding on the project implementation, the senior management of the Defence Department did not accept professionally processed analysis of the costs development, thus the impacts of the experiment can be described as a failure and a failure of management.

As following undertaken analysis proved, the economic objectives of the project in the form of cost reductions were achieved, which have been confirmed by subsequent quantitative data, however, the objective of targeting freed up military personnel for training as the main activity of the Armed Forces also proved to be very questionable.

After the introduction of outsourcing, the costs were reduced in $17.24 \%$ of the cases, they remained at the same level as before the introduction of outsourcing in $20.68 \%$ cases, in $34.48 \%$ of cases they increased, and in $27.60 \%$ of the cases internal organizational units failed to compare the evolution of the costs before and after the implementation of outsourcing (Jirásková, 2010).

In this context, an important indication is the fact that at least in minimum of $55 \%$ cases there was not a reduction in the cost of supplied services. Equally striking is the fact, that more than a quarter of the direct beneficiaries/recipients of the supplied services were not able to compare the evolution of the costs before and after the introduction of outsourcing. This is a result of the unacceptable centralization of decision-making in military logistics, where the implementation of this project was approved at the strategic level without the acceptance of comments from the tactical and operational level of the Armed Forces.

A prime example of such inefficiency and other negative impacts in the form of loss of capability or dissatisfaction with the quality of the supplied service, is the meal area. In the supply of the service from the external supplier, there have been carried out two possible approaches:

- the economic rental of meal facility of the Department of the Ministry of defence;

- imports of meals prepared at the service provider facility.

Second, minority form was applied at 5 out of 15 internal organizational units. The difference in costs compared to the first form was only the minimum (up to $10 \%$ ), therefore the data of difference between the provision of such services by internal resources of the Defence Department and by supplied form of the meal facility rental will be used as a relevant output of the costs analysis.

Based on "Analysis of the rations provision of the Armed Forces of the SR" elaborated by SCMM in Trenčín in 2011, which conducted the comparison of costs on dietary dose 1 prepared in internal conditions of the AF of the SR with the use of its own resources and contracted prices of external suppliers for the needs of 15 units and facilities with such provision of meals, it can be stated that that on average there was a growth of the cost of this form by $64.86 \%$. This increase in costs cannot be taken as relevant because it includes the cost of breakfast and dinner, which in terms of professional AF only minimum of soldiers take. 
If, because of the objectivity of outputs, we focus only on the lunch on their own funds, while the cost of their preparation by the own resources accounted for an average of euro 2.06 per dietary dose and according to individual suppliers the meals costs were in average by $52 \%$, i.e. $€$
1.07 higher, we can quantify the difference in the cost of meals to the detriment of outsourcing by the formula:

$\mathrm{QS} * \mathrm{QU} * \mathrm{QD} * \mathrm{QR} * \mathrm{RN}=\sum \mathrm{E}-\mathrm{I}$

$400 * 15 * 240 * 10 * 1,07=15408000 €$

Prices of meals in the economic rental of the catering facility

Table no. 1 and prices when prepared by own resources - comparison

\begin{tabular}{|c|c|c|c|c|c|c|c|}
\hline \multirow[t]{3}{*}{ Unit } & \multirow[t]{3}{*}{ Contractual partner } & \multicolumn{6}{|c|}{ Contract value of supplied meal } \\
\hline & & \multicolumn{3}{|c|}{$\begin{array}{c}\text { Dietary dose } 1 \\
\text { The value of meal in } \\
€\end{array}$} & \multicolumn{3}{|c|}{$\begin{array}{l}\text { Difference with the } \\
\text { AF of the SR in \% }\end{array}$} \\
\hline & & $\mathbf{B}$ & $\mathbf{L}$ & $\mathbf{D}$ & $\mathbf{B}$ & $\mathbf{L}$ & D \\
\hline $\begin{array}{l}\text { AF } \mathrm{SR}-\text { The } \\
\text { resources and me }\end{array}$ & preparation by own & 1,13 & 2,06 & 1,13 & $\mathbf{0}$ & $\mathbf{0}$ & $\mathbf{0}$ \\
\hline $\begin{array}{c}\text { Unit , facility } \\
\text { A }\end{array}$ & Supplier 1 & 2,51 & 3,18 & 2,51 & 122 & 54 & 122 \\
\hline $\begin{array}{c}\text { Unit, facility } \\
\text { B }\end{array}$ & Supplier 2 & 2,41 & 3,18 & 2,81 & 113 & 54 & 149 \\
\hline $\begin{array}{l}\text { Unit, facility } \\
\text { C }\end{array}$ & Supplier 3 & 1,17 & 3,00 & 1,17 & 4 & 46 & 4 \\
\hline $\begin{array}{c}\text { Unit, facility } \\
\text { D } \\
\end{array}$ & Supplier 4 & 1,16 & 3,14 & 1,16 & 3 & 52 & 3 \\
\hline $\begin{array}{l}\text { Unit, facility } \\
\text { E }\end{array}$ & Supplier 5 & 1,67 & 3,18 & 1,72 & 48 & 54 & 52 \\
\hline $\begin{array}{l}\text { Unit, facility } \\
\text { F }\end{array}$ & Supplier 6 & 3,04 & 3,49 & 3,04 & 169 & 69 & 169 \\
\hline $\begin{array}{c}\text { Unit, facility } \\
\text { G }\end{array}$ & Supplier 7 & 1,18 & 3,04 & 1,18 & 4 & 48 & 4 \\
\hline $\begin{array}{c}\text { Unit, facility } \\
\text { H }\end{array}$ & Supplier 8 & 1,70 & 3,38 & 2,26 & 50 & 64 & 100 \\
\hline $\begin{array}{c}\text { Unit, facility } \\
\text { I }\end{array}$ & Supplier 9 & 2,57 & 3,10 & 2,67 & 127 & 50 & 136 \\
\hline $\begin{array}{l}\text { Unit, facility } \\
\mathbf{J}\end{array}$ & Supplier 10 & 1,86 & 3,15 & 2,00 & 65 & 53 & 77 \\
\hline
\end{tabular}

(Source: Analysis of the rations provision, SCMM 2012 (unit numbers and trade names of suppliers were amended due to the legislative purpose)

In which: QS - average number of diners at a unit (a facility)

QU - number of units with contractual form of meals

QD -number of meals per a diner/per year

$\mathrm{QR}$ - duration of the contractual relationship (years)

$\mathrm{RN}$ - difference between external and internal costs per a dietary dose (in $€$ )

$\sum$ E-I - increase of costs between the external and the internal form of catering 
Devastating effect of externalisation in military logistics also increase the negative development in:

- the growth of the cost of the forced investment rate;

- loss of capability;

- unacceptable quality;

- unreliability of suppliers.

Dissatisfaction with the choice of the area of implementation of outsourcing in terms of cost, quality, reliability of suppliers, the loss of control over the provided services, confirms one of the conclusions of the professional assembly of logistics personnel organized by the department of logistics of the Staff for Support Operations of General Staff in the first half of 2015. On the basis of the analyses performed and the experience gained with the provision of services by external suppliers, it was decided to return to the provision of catering services by internal resources of the Ministry of Defence.

\section{Conclusion}

The meaning and the importance of the life-cycle cost estimate, as it is evident from the content of the contribution, do not concern only equipment and techniques, but also logistics services. An approach based on the assumption that they still make up only a tiny portion of the public funding of the defence is incorrect since irresponsible experiments in this area cause also the growth of costs. Negative impacts of outsourcing in some services are wider in scope. Logistic staff, which is responsible for preparing food in the event of a crisis in units with external catering, loses the professional competence a condition of which is the daily preparation of meal. When it comes to quantitatively limited offer of such service within the territory of the Slovak Republic, even the option of substitution, when there is a supplier failure, is considered as risky.

Short term contractual relationship with suppliers (max for a period of 4 years) is not motivating for lessors of catering services to carry out their building maintenance and necessary investment in the infrastructure needed to provide the service. The result is so-called forced investment which represents, after 10 years of experiment, about 15 million euro for the Ministry of defence of the Slovak Republic. This is another obstacle that hinders the implementation of the plan to return to the provision of services within the competence of the internal logistics elements of the resort.

This is just a part of a wider spectrum of interrelated consequences of decisions that are not always the primary views and expert opinions, but political and group interests focused on short-term effects, not always in accordance with the public interest and strategic objectives of the development of the defence.

\section{REFERENCES}

AAP - 20 NATO. (2015). Phased Armaments Programming System. Life Cycle Management, available at: http://www.nspa.nato.int/en/news/news-20130730-4.htm.

Jirásková, S. (2010). Outsourcing $v$ rezorte $M O S R$, available at: http://www.unob.cz/eam/Documents/Archiv/EaM_1_2010/Jir\%C3\%A1skov\%C3\%A1.pdf.

ŠbLog-V-277/2004. (2004). Zabezpečenie služieb v rozpočtovej organizácii MO SR na roky 2005 až 2008, GŠ OS SR Bratislava.

ÚSANM-9-15/2007-OZS. (2007). Zabezpečenie služieb v rozpočtovej organizácii MO SR na roky 2007 až 2010, MO SR Bratislava. 